\title{
IMPLICATIONS OF MORATORIUM ON ISLAMIC FINANCIAL
CUSTOMERS IN MALAYSIA
}

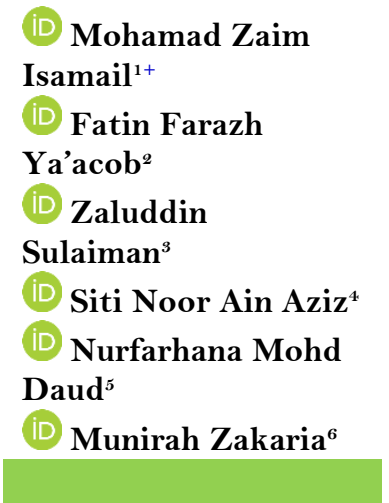

Article History

Received: 12 February 2021 Revised: 16 March 2021 Accepted: 19 April 2021 Published: 27 May 2021

\section{Keywords}

COVID-19

Moratorium

Islamic financial customers Movement control order (MCO)

Financial literacy

Financial planning.

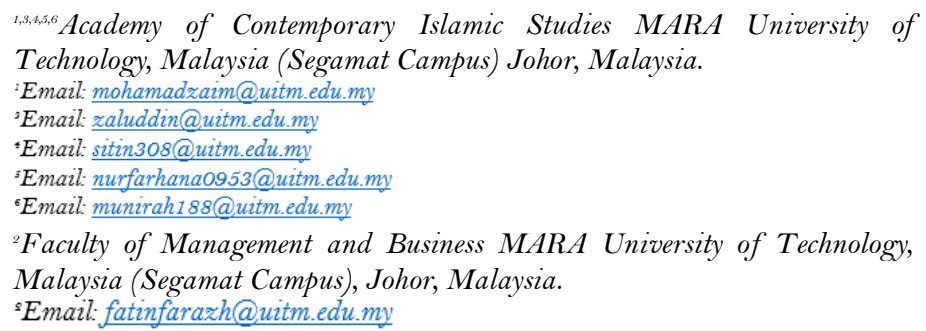

\begin{abstract}
Issues on moratorium are popular, intense, and often debated in the period of Movement Control Order (MCO) in Malaysia. Which is not the case, various interpretations and assumptions are given in defining moratorium. Politicians, financial practitioners, government sector workers and even the private sectors are affected by this situation. This article aims to examine the implications of the offered moratorium on Islamic financial customers. To achieve the objectives, this research's method uses a quantitative research approach in the form of field research. In addition, a total of 409 respondents answered the questionnaire using google form, and the data were analysed using SPSS version 23. The results of this study show that the percentage of people who know about the information regarding the moratorium implementation is more. In fact, the findings also show that the respondents preferred their money to be kept because of the implementation of the moratorium during the Movement Control Order (MCO) period. From the findings, the response on the appropriateness and extension of the moratorium on repayment from the bank is influenced by the type of employment of the respondents. Similarly, the relationship between responses to changes in the way customers pay is influenced by the respondents' type of employment.
\end{abstract}

Contribution/ Originality: This study evaluates the impact of the sixth-month automatic moratorium (2020) on Malaysian Islamic financial customers. Very limited studies illustrate its impact on Islamic financial clients' financial literacy and Islamic financial management. Some customers became prudent during the period. This study's findings show that employment type affects payment approach.

\section{INTRODUCTION}

\subsection{Background of the Study}

Around the end of 2019, a coronavirus outbreak (COVID-19) was detected for the first time in Wuhan province, China. This situation is not only life-threatening, but such phenomenon is also a major threat in economic sectors, where the global growth projections at the early stage were well below one-percentage point. Malaysia, which is economically dependent with other countries was also affected by the situation when the Malaysian 
government announced the Movement Control Order (MCO), closing almost all-important sectors. This situation resulted to more individuals losing their sources of income.

Similarly, the financial sector, which includes the banking institutions, also suffered the same fate. In addition to the needs to maintain liquidity in each of its banking institutions, the ability to maintain relationships between customers and banking institutions, as well as placing financial stability at the heart of the challenge is still a difficult task until today. Various efforts have been made by the government as well as Bank Negara Malaysia (BNM) in terms of fiscal and monetary policies to safeguard the country's economy from continuing to plummet. Among them was the six-month moratorium, making Malaysia as the first country to implement it for the benefits of its people and businesses. According to the statistics, a total of 7.7 million Malaysians received the benefit, with given moratorium value of RM59 billion. By definition, a moratorium is a period of time during which borrowers are not expected to pay their equated monthly instalment according to their current schedule (Somasundaram, 2020). This moratorium is implemented by the Malaysian Government for six months, endowed automatically from April 2020 to September 2020 by Bank Negara Malaysia (2020). From this situation, the implementation of the sixmonth moratorium was one of the earliest steps taken for the benefits of the Malaysian people and businesses. These efforts and measures were done considering the financial constraints of the borrowers. Apart from that, this situation also gave relief to the people, especially the bank customers to make loan repayments due to the stress of life in MCO period that restricted bank customers from working and earning income to cover their life expenditure that included bank debt burden. The rationale of this study is to prepare borrowers financially during the dynamics through financial education. This research examines the dynamic effects of COVID-19 on the financial health of individuals covering savings, spending, borrowing and planning. The importance of this study is a continuation of previous studies that stated the individuals aged 30 years and below are the highest age group of bankruptcy due to credit card debt and is believed to be due to excessive spending and poor financial management. Therefore, to reduce bankruptcy cases among youths is through knowledge and awareness related to financial management that should be disclosed as early as possible so that they are better prepared and have complete knowledge to become more successful individuals.

\subsection{Statement of the Problem}

The offer and implementation of the moratorium in Malaysia was so unique and received attention from other countries, especially Asian countries like Singapore, Indonesia, Thailand, and others. Indeed, the moratorium offered by BNM was seen as people-friendly, especially to the banks' own borrowers. However, in the excitement of enjoying the moratorium, various questions and issues arose to some extent, affecting BNM's reputation. The first issue that arose was related to financial literacy itself. This situation occurred when BNM caused some confusions when the offered moratorium was not automatic, and even the banks' customers had to self-inform the banks to be excluded from receiving the moratorium. Even to those who chose to defer monthly payments to banks, this situation is likely to lead to higher repayments after the moratorium period ends. This situation also stems from statements issued by BNM in such a hurry, using poorly constructed sentences that confused the public. So, with the confusion caused, criticism was thrown to BNM itself. The use of clear sentences and specific bank terms should be stated in a simpler manner with clear-cut meanings. This matter was also an issue that impacted many parties, following the implementation of the moratorium. Secondly, the financial planning of the moratorium itself proved to be an issue. This situation is indeed useful for bank customers who rely on the source of income earned from their respective employers. Which is not the case, there were employees being laid off, and expecting compensation from their former employers. In fact, there were also workers getting unpaid salaries, half salaries, and many more. All these situations contributed to how financial management and planning being done by the banks' customers during the moratorium period. For individuals without job or repayment difficulties, they had their own ways in managing their finances of whether to save money or use it for other purposes. So, like the problems mentioned above, this 
study was conducted to identify two issues: (1) to identify the level of financial literacy of individuals against the implementation of moratorium; and (2) to compare the level of an individual's financial planning due to the implementation of moratorium. Generally, this study investigates the impact of the implementation of the sixmonth automatic moratorium on Islamic financial customers in Malaysia. This study aims to answer the following questions:

1) How does identify the level of financial literacy of individuals against the implementation of the moratorium?

2) How does compare the level of individual financial planning as a result of the implementation of the moratorium?

\section{LITERATURE REVIEW}

\subsection{The Individual Financial Literacy towards the Implementation of the Moratorium}

Many are still confused and unclear with the concept of moratorium. According to Somasundaram (2020) the confusion includes the misconception that the repayment amount of a hire purchase loan. People have forgotten that only the term will be extended, and they will no longer be required to pay Equated Monthly Instalment (EMIs) according to their previous schedule but will now be required to pay interest on previously taken out principal and interest clubbed EMIs. Therefore, our Bank Negara Malaysia (BNM) advised borrowers that the interest will continue to accrue on deferred payments, and borrowers should be careful and thoughtful in deciding whether or not to take this moratorium. To ensure that the individuals can manage their financial situations effectively especially in the period of moratorium, knowledge is essential. In addition, the implementation of the moratorium emphasizes the importance of prudent financial management, including the establishment of emergency funds.

According to Latvian Insurers Association (2018), financial literacy is defined as the knowledge, ability or skill to apply knowledge in an individual about financial behavior, financial experience, and debt commitment literacy. Ahmad, Widyastuti, Susanti, and Mukhibad (2020) discussed that the word financial literacy is often used interchangeably with words like financial intelligence, financial capacity, financial education, and financial competence. The level of financial literacy is significantly influenced by demographic factors such as gender, age, and education; socio-economic factors such as income and occupation; and psychological factors such as future expectations (Kadoya \& Khan, 2020). In addition, the level of financial literacy of an individual can be expected when they use their possessed financial knowledge, have high financial experience, as well as showing a positive financial attitude. This is because when an individual has high knowledge and experience in finance, then, their financial affairs will also become more efficient and systematic, especially in unforeseen circumstances such as MCO.

However, since the start of MCO, only $29 \%$ Malaysians realized the importance of emergency funds. According to a study conducted by the Department of Statistics Malaysia. (2020), a total of $71.4 \%$ of self-employed respondents had sufficient savings to survive for less than a month, followed by private employees, accounting for $58 \%$, and employers accounting for a total of $49.2 \%$. Only $2.4 \%$ of self-employed respondents had 6 -month savings. At the same time, during this period, only $3.6 \%$ and $5.5 \%$ of private sector workers and employers had savings. Therefore, the results of this survey reflect the financial health of Malaysians who lack knowledge about financial management.

\subsection{The Level of Individual Financial Planning During the Implementation of the Moratorium}

According to the Malaysian Financial Literacy Survey 2020, there was a significant increase for those who saved money, where the loan moratorium helped them to put more money into their savings for difficult times, even though it is not practiced by all income groups. This is different from last year, before the moratorium.

Borrowers must assess their financial situation to determine if they can afford to repay their loans once the moratorium ends. However, $16 \%$ of the respondents said that they were unready to resume paying their loans after the moratorium period ended (Malaysian Financial Literacy Survey, 2020). These groups were urged to seek initial assistance by contacting their respective financial institutions or AKPK to discuss these problems and seek financial 
advice (Nurul, 2020). According to ABM, more than 7.7 million borrowers took advantage of the lending moratorium, indicating that 1.2 million borrowers needed post-moratorium assistance (Malaysian Financial Literacy Survey, 2020). For those whose income was not affected but chose to accept deferment, it is expected that they have no problems in repaying the loans once the deferral is over. The importance of this study is a continuation of previous studies, where Abdullah, Fazli, and Arif (2019) revealed that people aged 40 and below lacked financial literacy when it came to bankruptcy and they are the highest age group of bankruptcy due to credit card debt, happening due to excessive spending and poor financial management. Therefore, to reduce bankruptcy cases among youths is through knowledge and awareness related to financial management that should be disclosed as early as possible so that they are better prepared and have complete knowledge to become more successful individuals. In addition, with a survey report released by AKPK stating that a total of 64,633 individuals were declared bankrupt and its relationship with financial literacy or financial literacy in Malaysia and also globally where this is due to lack of financial knowledge, poor financial behavior, job instability, rising cost of living and debt burden, which is said to be the cause of bankruptcy (Abd Rahman \& Sarib, 2020). Bankruptcy cases among youth and educated individuals are not an unusual issue these days. There are many reports of bankruptcy cases recorded and among the factors that are often seen as contributing to these bankruptcy cases are due to the lack of knowledge on financial management. Abdullah et al. (2019) reported that most of the young workers are in debt as a result of factors such as poor financial management and income that does not cover expenses.

\subsection{Past Studies}

In contrary to researchers like (Muhammad \& Mohd-Yahya, 2016) they examined the extent to which external financial assistance is significant to economic development. Four development indicators as a measure of financial assistance were analyzed: (1) economic growth rate, (2) education index, (3) life expectancy index and (4) human development index, using panel data method. The results of regression found that significant financial assistance helped ASEAN countries to achieve development goals. As a result, the findings of this study imply that any external financial assistance is important in helping the development of a country. This is also achieved through the effective expenditure of the financial assistance that is received. A similar finding was also obtained when Bank Simpanan Nasional (BSN) in 2017 strengthened its corporate responsibility initiatives by handing over RM200,000 in daily necessities assistance to 1,000 families of victims in the flood-affected states. This initiative or assistance aimed to alleviate the burden of flood victims so that they can start living as usual after the disaster (Bank Simpanan Nasional, 2017). A similar situation also happened in the middle of 2020, where the Yayasan Bank Rakyat donated Aidilfitri assistance to 200 orphans. These noble efforts and steps were indeed necessary, and aids such as Malay dress (baju raya) equipment, money, and other forms of support also help ease the burden of the orphans.

\section{METHODOLOGY}

This study uses a quantitative research approach in the form of field research. The design of this study used survey data to achieve the objectives of the study. Survey research is a research methodology that involves a collection of data from the population to understand the current situation related to the population, as well as the variables. Accordingly, this survey study is also an appropriate method to obtain information in the forms of opinions, attitudes, and perceptions of a population from the respondents who were sampled. To do that, the researchers distributed an online questionnaire (online survey) to the selected sample, and the information obtained from the questionnaire was analyzed to achieve the objectives of the study. In this survey study, the researcher used a cross-sectional type of study where the data was collected at one time only.

The technique used for this sampling was random sampling (Cluster Sampling). By using this technique, the researcher distributed an online survey by focusing on customers of Islamic financial institutions throughout Malaysia, and the target was a total of 500 respondents of Islamic financial institutions' customers. Thus, the 
population in this study consists of Islamic finance customers throughout Malaysia (employee population across Malaysia: 15.32 million) (Department of Statistics Malaysia, 2020). Of that, the statistics show that more than 7.7 million individual borrowers (Muhyiddin, 2020) benefited from the moratorium. In addition, a total of 500 target respondents who were Islamic financial customers throughout Malaysia opted for the moratorium. Thus, from the target number of respondents, the researchers selected a study sample of 400 Islamic financial customers who chose the moratorium throughout Malaysia, even though the maximum number of respondents is only 382 , based on the theory of sampling method (Krejcie \& Morgan, 1970). In addition, it is intended to accommodate the damaged samples. The number of samples selected for each of these customers is as follows:

Table-1. Determination of krejcie and morgan sample volume.

\begin{tabular}{c|c|c|c|c|c}
\hline $\mathbf{N}$ & $\mathbf{S}$ & $\mathbf{N}$ & $\mathbf{S}$ & $\mathbf{N}$ & $\mathbf{S}$ \\
\hline 10 & 10 & 220 & 140 & 1200 & 291 \\
\hline 15 & 14 & 230 & 144 & 1300 & 297 \\
\hline 20 & 19 & 240 & 148 & 200 & 320 \\
\hline 80 & 66 & 420 & 201 & 3500 & 346 \\
\hline 100 & 80 & 500 & 217 & 6000 & 360 \\
\hline 150 & 108 & 750 & 254 & 2000 & 375 \\
\hline 200 & 132 & 1000 & 278 & 3000 & 382 \\
\hline
\end{tabular}

\section{FINDINGS}

\subsection{Introduction}

This section presents the findings of the study. The findings are presented based on the research questions that they answer. In addition, the findings were made through descriptive and chi square analyses. The discussion of the descriptive analysis focuses on the description of the background of the respondents, and the financial literacy of the individuals towards the implementation of the moratorium. The discussion of chi square analysis was also done to see the comparison of the level of individual financial planning due to the implementation of the moratorium. The analysis also answers each existing issue stated in the introduction.

\subsection{Findings for Descriptive Analysis (Demography)}

According to Krejcie and Morgan's theory, the total target for data collection is 382 respondents, and the researchers targeted to collect 500 respondents by considering the damage factor on the to-be-obtained data. As the study and data collection were conducted, the results of the data collection reached a total of 409 respondents.

\subsection{Findings for Descriptive Analysis of Demographic Information}

The analysis of demographic information was initiated by isolating each of the demographic items, and the items constructed in this section were related to the number of categories of gender, ethnicity, age, education, residence information, occupation, and employment status during the Movement Control Order (MCO). The descriptive analysis was used to test the demographic variables. Table 2 shows the number and percentage of respondents who followed each demographic variable.

Based on Table 2, out of 409 respondents, a total of 187 people or 45.7 percent are males, while the remaining 222 people or 54.3 percent are females. From Table 2 , it can be concluded that the number of females who answered the questionnaire was more than males. In addition, the results also show the number and percentage of the respondents by ethnicity. Out of the 409 respondents, a total of 401 people, or 98 percent are Malays, followed by 5 people or 1.2 per cent are Others, and the remaining 3 people, representing 0.7 percent are Chinese.

Table 2 also shows the number and percentage of the respondents by age. Out of the 409 respondents, the majority is 202 people representing 49.4 percent are under the category of 30-39 years old, followed by 109 people $(26.7 \%)$ under the category of 21-29 years old. Fourteen people (3.4\%) are under the category of below 20 years old, 
followed by 19 people (4.6\%) aged 50 years old and above, making them the smallest age groups who answered the questionnaire.

Table-2. Descriptive statistics of demographic variables.

\begin{tabular}{|c|c|c|c|}
\hline Variable & Category & Number (people) & Percentage (\%) \\
\hline \multirow[t]{2}{*}{ Gender } & Male & 187 & 45.7 \\
\hline & Female & 222 & 54.3 \\
\hline \multirow[t]{3}{*}{ Ethnicity } & Malay & 401 & 98.0 \\
\hline & Chinese & 3 & 0.7 \\
\hline & Others & 5 & 1.2 \\
\hline \multirow[t]{5}{*}{ Age } & Under 20 years old & 14 & 3.4 \\
\hline & 21 years -29 years & 109 & 26.7 \\
\hline & 30 years -39 years & 202 & 49.4 \\
\hline & 40 years -49 years & 65 & 15.9 \\
\hline & 50 years and above & 19 & 4.6 \\
\hline \multirow[t]{6}{*}{ Higher Education Level } & SPM & 43 & 10.5 \\
\hline & Certificate & 7 & 1.7 \\
\hline & STPM / Matriculation / Diploma & 96 & 23.5 \\
\hline & Bachelor's Degree & 178 & 43.5 \\
\hline & Master's Degree & 49 & 12.0 \\
\hline & $\mathrm{PhD}$ & 36 & 8.8 \\
\hline \multirow{3}{*}{ Residential Info } & Urban & 255 & 62.3 \\
\hline & Suburban & 113 & 27.6 \\
\hline & Rural & 41 & 10.0 \\
\hline \multirow[t]{4}{*}{ Job Type } & Government & 176 & 43.0 \\
\hline & Statutory Body & 98 & 23.9 \\
\hline & Private & 110 & 26.9 \\
\hline & Self-employed & 25 & 6.1 \\
\hline \multirow{6}{*}{$\begin{array}{l}\text { Job Status During Movement } \\
\text { Control Order (MCO) }\end{array}$} & Directed to Take Leave & 30 & 7.3 \\
\hline & Partial Leave (On Standby) & 21 & 5.1 \\
\hline & Work from Home & 236 & 57.7 \\
\hline & Shift Work & 44 & 10.8 \\
\hline & Unable to Work & 11 & 2.7 \\
\hline & Not Applicable & 67 & 16.4 \\
\hline
\end{tabular}

Then, the number and percentage of respondents according to the level of education follows. Out of the 409 respondents, most of the respondents, which are 178 people $(43.5 \%)$ possess university degree, followed by 96 people (23.5\%) possess STPM/Matric/Diploma certificates. While the lowest and highest level of education is 7 people (1.7\%), being Certificate holders, followed by 36 people $(8.8 \%)$ being $\mathrm{PhD}$ holders. Next, the results show the number and percentage of respondents by place of residence. Out of the 409 respondents, the highest number is 255 people $(62.3 \%)$ coming from the city area, while the lowest number is 41 people $(10 \%)$ coming from the suburbs.

Table 2 shows the number and percentage of respondents by Occupation Type. Out of the 409 respondents, the highest number is 176 people (43\%) being government servants, followed by 110 people (26.9\%) who are private sector workers. The lowest number is 25 people (6.1\%), and they are self-employed. Table 2 shows the number and percentage of respondents who follow the Current Work Status of MCO. Out of the 409 respondents, the highest number is 236 people $(57.7 \%)$ who worked as normal, followed by 67 people $(16.4 \%)$ percent having unrelated status. The lowest number is 11 people (2.7\%), who are unable to work, followed by 21 people which is 5.1 percent, being on partial holiday status.

\subsection{Findings for Descriptive Analysis (Individual Financial Literacy)}

The first objective of this study was to identify the level of financial literacy of individuals towards the implementation of moratorium. Eight questions were asked to the respondents in the distributed questionnaire form. The descriptive analysis was used to test this first objective. This also covers the frequency of right and 
wrong for each question asked to test the level of financial literacy of individuals regarding the implementation of moratorium. Table 3 shows the number and percentage of respondents who follow each question that was asked to the respondents, where there were eight questions in total.

Table-3. Descriptive individual financial literacy statistics.

\begin{tabular}{l|l|c|c}
\hline Question & $\begin{array}{l}\text { Respondent's } \\
\text { Answer }\end{array}$ & $\begin{array}{l}\text { Number } \\
\text { Percentage }\end{array}$ \\
\cline { 2 - 3 }$(\mathbf{p e o p l e )}$ & $(\mathbf{\%})$ \\
\hline Moratorium Means & FALSE & 1 & 0.2 \\
\hline Postponement of Payment & TRUE & 408 & 99.8 \\
\hline The Moratorium Starts in April 2020 & FALSE & 10 & 2.4 \\
\cline { 2 - 3 } & TRUE & 399 & 97.6 \\
\hline Bank Negara Malaysia (BNM) Has Imposed & FALSE & 45 & 11.0 \\
\hline The Moratorium During the Movement Control Order Period & TRUE & 364 & 89.0 \\
Only & & \multicolumn{2}{|c}{} \\
\hline The Moratorium Period Granted by Bank Negara Malaysia & FALSE & 12 & 2.9 \\
\hline BNM) Is For 6 Months & TRUE & 397 & 97.1 \\
\hline Any Information Related to The Moratorium Can Be Obtained & FALSE & 47 & 11.5 \\
\hline From Social Media. & TRUE & 362 & 88.5 \\
\hline The Moratorium Is Given to All Financial & FALSE & 25 & 6.1 \\
\hline Customers Who Have Made Loans with Their Respective Bank & TRUE & 384 & 93.9 \\
\hline Information Ambiguity By BNM & FALSE & 30 & 7.3 \\
\cline { 2 - 4 } & TRUE & 379 & 92.7 \\
\hline The Moratorium & FALSE & 258 & 63.1 \\
\hline Causes Banking Institutions to Sustain Losses & TRUE & 151 & 36.9 \\
\hline
\end{tabular}

Table 3 shows the number and percentage of respondents who answered the question regarding the meaning of moratorium, i.e. moratorium means the deferment of payment. Of the 409 respondents, 408 people (99.8\%) answered "correct", while 1 person $(0.2 \%)$ answered "wrong". Table 3 shows the number and percentage of respondents who answered questions regarding the moratorium that started in April 2020. Out of the 409 respondents, 399 people (97.6\%) answered “correct", while 10 people (2.4\%) answered "wrong”. Table 3 shows the number and percentage of respondents who responded that Bank Negara Malaysia (BNM) had imposed moratorium during the period of the Movement Control Order only. Out of the 409 respondents, most of the respondents or 364 people (89\%) answered "correct", and 45 people (11\%) answered "wrong". Table 3 shows the number and percentage of respondents who responded. The moratorium period given by Bank Negara Malaysia (BNM) was for 6 months. Out of the 409 respondents, 397 people (97.1\%) answered "correct", while 12 people (2.9\%) answered "wrong".

Table 3 shows the number and percentage of respondents who answered the question of "Any information related to the moratorium can be obtained through reading on social media". Out of the 409 respondents, 362 people (88.5\%) answered "correct", while the rest answered "wrong" (47 people or 11.5\%). Table 3 shows the number and percentage of respondents who answered the question of "the Moratorium given to all financial customers who make loans with banks". Out of the 409 respondents, 384 people (93.9\%) answered "correct”, while the rest answered "wrong" (25 people or 6.1\%). Table 3 shows the number and percentage of respondents who responded that "Sometimes the ambiguity in conveying information by Bank Negara Malaysia (BNM) by using vague terms related to the moratorium causes financial customers to be confused and dissatisfied". Out of the 409 respondents, 379 people (92.7\%) answered “correct", while the rest answered "wrong” (30 people or 7.3\%). Table 3 shows the number and percentage of respondents who answered the question of "the Moratorium giving losses to banking institutions". Out of the 409 respondents, most people gave "wrong" answer (258 people or 63.1\%) while only 151 people (36.9\%) answered "correct". 
Table-4. Examining the relationship of financial planning to Islamic financial clients.

\begin{tabular}{|c|c|c|c|c|c|c|c|c|c|c|c|c|c|c|c|c|}
\hline \multicolumn{2}{|c|}{ Item } & \multirow[t]{2}{*}{ Frequency } & \multicolumn{2}{|l|}{ Gender } & \multicolumn{2}{|c|}{ Ethnicity } & \multicolumn{2}{|l|}{ Age } & \multicolumn{2}{|c|}{$\begin{array}{l}\text { Higher } \\
\text { Education Level }\end{array}$} & \multicolumn{2}{|c|}{$\begin{array}{l}\text { Residential } \\
\text { Info }\end{array}$} & \multicolumn{2}{|c|}{ Job Type } & \multicolumn{2}{|c|}{$\begin{array}{l}\text { Job Status During } \\
\text { Movement Control } \\
\text { Order (MCO) }\end{array}$} \\
\hline & Optional & & $\begin{array}{l}\text { Chi } \\
\text { square }\end{array}$ & Sig. & $\begin{array}{l}\text { Chi } \\
\text { square }\end{array}$ & Sig. & $\begin{array}{l}\text { Chi } \\
\text { square }\end{array}$ & Sig. & $\begin{array}{l}\text { Chi } \\
\text { square }\end{array}$ & Sig. & $\begin{array}{l}\text { Chi } \\
\text { square }\end{array}$ & Sig. & $\begin{array}{l}\text { Chi } \\
\text { square }\end{array}$ & Sig. & $\begin{array}{l}\text { Chi } \\
\text { square }\end{array}$ & Sig. \\
\hline \multirow[t]{6}{*}{$\mathrm{S} 1$} & How does the implemer & on of the mor & torium d & ring th & Movemer & $t$ Contrc & Order $(\mathrm{N}$ & $\mathrm{CO})$ af & ct your $\mathrm{f}$ & ncial pl & ning? & & & & & \\
\hline & Financial Saving & 227 & \multirow{5}{*}{2.251} & \multirow{5}{*}{0.522} & \multirow{5}{*}{1.179} & \multirow{5}{*}{0.978} & \multirow{5}{*}{18.569} & \multirow{5}{*}{0.990} & \multirow{5}{*}{29.170} & \multirow{5}{*}{0.015} & \multirow{5}{*}{9.831} & \multirow{5}{*}{0.132} & \multirow{5}{*}{20.026} & \multirow{5}{*}{0.171} & \multirow{5}{*}{20.919} & \multirow{5}{*}{0.139} \\
\hline & Regular Spending & 101 & & & & & & & & & & & & & & \\
\hline & Investing & 21 & & & & & & & & & & & & & & \\
\hline & Paying Off Debt/Loan & 60 & & & & & & & & & & & & & & \\
\hline & Total & 409 & & & & & & & & & & & & & & \\
\hline \multirow[t]{4}{*}{$\mathrm{S} 2$} & \multicolumn{16}{|c|}{ The implementation of the moratorium allows retrenched customers to reduce their financial burden. } \\
\hline & True & 398 & \multirow{3}{*}{1.462} & \multirow{3}{*}{0.227} & \multirow{3}{*}{0.226} & & & & & & & & & & & \\
\hline & False & 11 & & & & 0.893 & 9.946 & 0.410 & 6.462 & 0.264 & 1.118 & 0.572 & 3.179 & 0.672 & 11.076 & 0.50 \\
\hline & Total & 409 & & & & & & & & & & & & & & \\
\hline S3 & Some financial custome & not take the & moratoril & $m$ and $c$ & ontinue to & repay & ank loan & as usua & & & & & & & & \\
\hline & True & 400 & & & & & & & & & & & & & & \\
\hline & False & 9 & 1.627 & 0.202 & 0.184 & 0.912 & 8.180 & 0.850 & 11.407 & 0.044 & 0.136 & 0.934 & 6.181 & 0.289 & 2.873 & 0.720 \\
\hline & Total & 409 & & & & & & & & & & & & & & \\
\hline $\mathrm{S} 4$ & Although banks allow $t$ & customers tc & fer pay & ents, d & ily opera & ional cc & t on beh & aff of th & ustomel & emains & e same o & contin & es to inc & ease. & & \\
\hline & True & 334 & & & & & & & & & & & & & & \\
\hline & False & 75 & 0.33 & 0.856 & 1.832 & 0.400 & 4.872 & 0.301 & 5.385 & 0.371 & 4.590 & 0.101 & 3.402 & 0.638 & 7.125 & 0.211 \\
\hline & Total & 409 & & & & & & & & & & & & & & \\
\hline S5 & Most financial custome & e not able to & anage th & ir finar & ces even i & banks & llow the & to def & paymen & & & & & & & \\
\hline & True & 317 & & & & & & & & & & & & & & \\
\hline & False & 92 & 0.487 & 0.485 & 2.368 & 0.306 & 8.100 & 0.088 & 2.211 & 0.819 & 0.196 & 0.907 & 37.721 & 0.000 & 4.024 & 0.546 \\
\hline & Total & 409 & & & & & & & & & & & & & & \\
\hline
\end{tabular}




\subsection{Examining the Relationship between Financial Planning and Islamic Financial Clients by Gender}

Table 4 shows the results of the analysis, to see whether there is an influence between the gender factors of Islamic financial customers and the level of financial planning on the implications of the implementation of the moratorium. The findings of the study for item 1 showed that the respondents preferred their money to be kept, as a result of the implementation of the moratorium during the Movement Control Order (MCO). Chi Square value $=$ 2.251 and $\mathrm{p}=0.522$ ( $\mathrm{p}>0.05)$ were insignificant. Similar with questions 2, 3, 4 and 5, the respondents chose the answer 'Correct' for each question posed. Respectively, all Chi Square and Asymp.Sig values were for item 2 (Chi Square $=1.462, \mathrm{p}=0.227)$, item $3($ Chi Square $=1.627, \mathrm{p}=0.202)$, item $4($ Chi Square $=0.33, \mathrm{p}=0.856)$, and item $5($ Chi Square $=0.487, p=0.485)$ were insignificant $(\mathrm{p}>0.05)$. This indicates that the gender difference of the customer does not affect the method of customer spending in financial planning after the implementation of the moratorium. Yet, this study contradicts the study of Trizah and Abdullah (2014) who claimed that gender has a correlation with the level of financial literacy.

\subsection{Examining the Relationship between Financial Planning and Islamic Financial Clients by Ethnicity}

The results of the overall inter-ethnic crosstab with the level of financial planning on the implementation of the moratorium showed that the respective Chi Square values for item 1 were $1.179, \mathrm{p}=0.978(\mathrm{p}>0.05)$, item 2 was 0.226, $\mathrm{p}=0.893$, item 3 was $0.184, \mathrm{p}=0.912$, item 4 was $1.832, \mathrm{p}=0.400$ and item 5 was $2.368, \mathrm{p}=0.306$ as insignificant because they had a higher value of 0.05 ( $p>0.05$ ). It can be concluded that this type of ethnicity has no relationship with the level of financial planning of Islamic financial clients in relation to the implementation of the moratorium.

\subsection{Examining the Relationship between Financial Planning for Islamic Financial Clients by Age}

Table 4 also shows the results of the analysis of differences in the level of financial planning of the respondents on the implementation of the moratorium as a whole. The findings showed that only the value of Chi Square for item 2 was 9.946, $\mathrm{p}=0.041$ which means it is below the value of 0.05 . This shows that respondents who chose 'Correct' by age category had an influence on the level of financial planning on the implementation of the moratorium that allows retrenched financial clients to reduce their burden. For questions 1, 3, 4 and 5, they showed a significant value of higher than $0.05(\mathrm{p}>0.05)$ and were not significant.

\subsection{To Study the Relationship between Financial Planning Towards Islamic Financial Clients According to Education Level}

The results of the overall crosstab between education level and financial planning of Islamic finance clients on the implementation of the moratorium showed that the respective Chi Square values for item 1 were 29.170, p = 0.015 , item 2 was $6.462, \mathrm{p}=0.264$, item 3 was $11.407, \mathrm{p}=0.044$, item 4 is $5.385, \mathrm{p}=0.371$ and item 5 is $2.211, \mathrm{p}=$ 0.819. Two items affect the level of education with the financial planning of Islamic finance customers, and they have a significant value of below 0.05 , namely items $1(\mathrm{p}=0.015)$ and $3(\mathrm{p}=0.044)$. This study is supported by Trizah and Abdullah (2014) and Almenberg and Säve-Söderbergh (2011) who found that higher educated individuals are more knowledgeable in financial literacy than the lower educated ones.

\subsection{Studying the Relationship between Financial Planning for Islamic Financial Clients by Place of Residence}

The results of the overall crosstab between residence and financial planning of Islamic financial clients on the implementation of the moratorium showed that the respective Chi Square values for item 1 were 9.831, p = 0.132, item 2 was $1.118, \mathrm{p}=0.572$, item 3 was $0.136, \mathrm{p}=0.934$, item 4 is $4.590, \mathrm{p}=0.101$ and item 5 is $0.196, \mathrm{p}=0.907$. There was no significant difference between residence with the following items. This indicates that residence does not influence financial planning towards the implementation of the moratorium. 


\subsection{Examining the Relationship between Financial Planning for Islamic Finance Clients by Type of Occupation}

The results of the overall crosstab between the type of employment with the financial planning of Islamic financial clients against the implementation of the moratorium showed that the respective Chi Square value for item 1 was $20.026, p=0.171$, item 2 was $3.179, p=0.672$, item 3 was $6.181, p=0.289$, item 4 was $3.402, p=0.638$ and item 5 was $37.721, \mathrm{p}=0.00$. Item 5 alone has a significant value that is the category of employment affects the financial planning of the respondents in terms of financial management ability even if the bank gives deferment of payment. This finding contradicts the result obtained by Mohd-Amim, Husniyah, and Ab Mumin (2015) who found that there was no difference in terms of financial planning based on job category. They thought that job category was not important in determining whether financial planning is done regularly or not.

\subsection{Studying the Relationship between Financial Planning and Islamic Finance Clients According to Employment Status during $M C O$.}

The results of the overall crosstab between the work status during MCO with the financial planning of Islamic financial clients against the implementation of the moratorium showed that the respective Chi Square value for item 1 was 20.919, $\mathrm{p}=0.139$, item 2 was $11.076, \mathrm{p}=0.050$, item 3 was $2.873, \mathrm{p}=0.720$, item 4 is $7,125, \mathrm{p}=0.211$ and item 5 is 4,024, $\mathrm{p}=0.546$. All $\mathrm{p}$ values for the following items were more than the significant value of 0.05 . This indicates that the level of financial planning of Islamic finance clients is not influenced by the employment status of the respondents during MCO.

Overall, from Table 4 it is found that most of the questions asked do not have a strong relationship to the level of financial planning of Islamic financial clients. However, also seen in Table 4 each question that was asked shows that most respondents have a good financial planning. This is also evidenced by each question such as items $1,2,3$, 4, 5, where most respondents answered 'Correct'.

\section{CONCLUSION}

Indeed, the offered moratorium was a good and noble effort for Malaysians in particular. Of course, various implications, whether positive or negative, also occurred during the implementation of the moratorium. Various interpretations and understandings also occurred among customers of Islamic financial institutions regarding the moratorium. Therefore, this study aims to identify the level of financial literacy of individuals towards the implementation of the moratorium. This study found that the level of financial literacy of individuals against the implementation of the moratorium was so high. Based on the questions posed to the Islamic financial clients, it is clear that they had shown a high level of literacy especially in relation to the moratorium. In addition, a comparison of the level of individual financial planning due to the implementation of the moratorium can also be seen from the tables presented. Various individual financial planning during the moratorium, and the relationship between the questions posed on individual financial planning with the implementation of this moratorium can also be seen.

Funding: The authors gratefully acknowledge the funding provided by Universiti Teknologi MARA Johor, for this research project. Through its financial fund, this project is finally completed.

Competing Interests: The authors declare that they have no competing interests.

Acknowledgement: All authors contributed equally to the conception and design of the study.

\section{REFERENCES}

Abd Rahman, I., \& Sarib, M. Y. M. (2020). The level of financial literacy among public sector employees: A study of Majlis Amanah Rakyat (MARA). Advanced Journal of Accounting and Finance, 2(2), 1-13.

Abdullah, N., Fazli, S. M., \& Arif, A. M. M. (2019). The Relationship between attitude towards money, financial literacy and debt management with young worker's financial well-being. Pertanika Journal of Social Sciences and Humanities, 27(1), 361387. 
Ahmad, G., Widyastuti, U., Susanti, S., \& Mukhibad, H. (2020). Determinants of the Islamic financial literacy. Accounting, 6(6), 961-966. Available at: 10.5267/j.ac.2020.7.024.

Almenberg, J., \& Säve-Söderbergh, J. (2011). Financial literacy and retirement planning in Sweden. Journal of Pension Economics E Finance, $10(4)$, 585-598.

Bank Negara Malaysia. (2020). This moratorium is implemented by the Malaysian Government for six months. Retrieved from: https://www.bnm.gov.my/documents/20124/2294076/Soalan\%20Lazim_Pakej\%20Penangguhan\%20dan\%20Pertuka ran\%2020200421.pdf.

Bank Simpanan Nasional. (2017). Yayasan Bank Rakyat donated Aidilfitri assistance to 200 orphans. Retrieved from: https://www.parlimen.gov.my/ipms/eps/2018-10-15/ST.66.2018\%20\%20BSN\%20Laporan\%20Tahunan\%202017.pdf.

Department of Statistics Malaysia. (2020). A total of $71.4 \%$ of self-employed respondents had sufficient savings to survive for less than month. from: https://www.dosm.gov.my/v1/uploads/files/6_Newsletter/Newsletter\%202020/DOSM_MBLS_2-2020-Siri_40.pdf.

Department of Statistics Malaysia. (2020). Employee population across Malaysia: 15.32 million. Retrieved from: https://www.dosm.gov.my/v1/index.php?r=column/pdfPrev\&id=TlExQUpsMENJcERaV2tvblM5MjRwQTo9.

Kadoya, Y., \& Khan, M. (2020). What determines financial literacy in Japan? Journal of Pension Economics and Finance, 19(3), $353-$ 371. Available at: $10.1017 / \mathrm{S} 1474747218000379$.

Krejcie, R. V., \& Morgan, D. W. (1970). Determining sample size for research activities. Educational and Psychological Measurement, 30(3), 607-610.

Latvian Insurers Association. (2018). Financial litaracy. Retrieved from: http://www.laa.lv/klientiem/finansu-pratiba/.

Malaysian Financial Literacy Survey. (2020). 16\% of the respondents said that they were unready to resume paying their loans after the moratorium period ended. Retrieved from: https://www.fenetwork.my/wpcontent/uploads/2020/11/RinggitPlus-Financial-Literacy-Survey-Full-Report.pdf.

Mohd-Amim, O., Husniyah, A. R., \& Ab Mumin, A. G. (2015). Financial planning and financial well -being among Muslim civil servants. Malaysian Consumer Journal, 24, 96-112.

Muhammad, A. A. R., \& Mohd-Yahya, M. H. (2016). Financial assistance and economic development in ASEAN: The Kuznets Hypothesis. Malaysian Economic Journal, 50(1), 99-110.

Muhyiddin, M. Y. (2020). More than 7.7 million individual borrowers benefited from the moratorium. Retrieved from: https://www.bharian.com.my/berita/nasional/2020/07/716065/lebih-77-juta-peminjam-nikmati-moratorium-rm383bilion.

Nurul, H. I. (2020). Covid War-19: How knowledge of finance can help in new norms. Retrieved from: https://www.bernama.com/bm/am/news_covid-19.php?id=1835940.

Somasundaram, M. (2020). Merits and demerits of moratorium offered by banks and non- banking financial companies in India. Asia Pacific Journal of Research, 1(1), 2347-4793.

Trizah, T. M., \& Abdullah, I. A. (2014). Determinants of financial literacy levels among employees of Kenya ports authority in Kenya. Research Journal of Finance and Accounting, 5(16), 44-52.

Views and opinions expressed in this article are the views and opinions of the author(s), International Journal of Asian Social Science shall not be responsible or answerable for any loss, damage or liability etc. caused in relation to/arising out of the use of the content. 